\title{
Specify Molecular Abnormality Analysis Method
}

National Cancer Institute

\section{Source}

National Cancer Institute. Specify Molecular Abnormality Analysis Method. NCI

Thesaurus. Code C158954.

A request to enter the specific molecular analysis method used to detect abnormalities in the study. 